\title{
Cytogenetical and histochemical studies on curcumin in male rats
}

\author{
A. El-Makawy ${ }^{1} \&$ H. A. Sharaf ${ }^{2}$ \\ ${ }^{I}$ Department of Cell Biology, National Research Center, Giza, Egypt \\ ${ }^{2}$ Department of Pathology, National Research Center, Giza, Egypt
}

\begin{abstract}
Curcumin is a major component of the curcuma species, commonly used as a yellow coloring and flavoring agent in foods. Curcumin has been demonstrated to have potent antioxidant, anti-inflammatory activity and has shown anticancer properties in many rodent models. There is the perception that since compounds are natural, they are devoid of toxicity and safe to use. Some of the active compounds in supplements have inherent toxicity. In this study, five doses $(0.5$, $5,10,25$ and $50 \mathrm{mg} / \mathrm{kg} /$ daily) of curcumin spice were orally administered to male rats daily for four weeks. The effect of curcumin was studied genetically by evaluation of chromosomal aberrations and micronucleus formation in bone marrow cells of male rats. Histopathological and histochemical investigations were studied in different tissues (liver, kidney) of males. The cytogenetical results showed that curcumin caused a statistically significant dose-dependent increase in the number of micronucleated polychromatic erythrocytes (MNPCEs) and in the frequencies of total chromosomal aberrations over the control. Also, results showed that there were significant differences between positive control and all curcumin-tested doses, except the dose of $50 \mathrm{mg} / \mathrm{kg}$ showed no significant difference. Histopathological results showed different degrees of alterations, as manifested by vacuolar degeneration in hepatocytes, tubular degeneration in renal tissues. We conclude that over use of curcumin spice may cause genotoxical and histopathological effects.

Keywords: curcumin spice, ADI, bone marrow, chromosome aberrations, micronucleus polychromatic erythrocytes (MNPCEs), liver, kidney.
\end{abstract}




\section{Introduction}

Tumeric is a spice that comes from the root Curcuma longa, a member of the ginger family, Zingaberaceae. Curcuminoids are components of tumeric, which include mainly curcumin (diferuloyl methane), demethoxycurcumin and bisdemethoxycurcmin [1]. Curcumin, bis(4-hydroxy-3-methoxyphenyl)-1,6diene-3,5-dione, is a yellow-orange dye derived from the rhizome of the plant Curcuma longa. Curcumin is widely used as a spice and coloring agent in several foods, such as curry, mustard, bean cake, cassava paste and potato chips, as well as in cosmetics and drugs [2]. It exhibits chemopreventive and growth inhibitory activity of the initiation and promotion of many cancers [3, 4]. The dietary photochemical curcumin possesses anti-inflammatory, antioxidant, and cytostatic properties. Curcumin acts as a potent anticarcinogenic compound. Curcumin induces apoptotic cell death by DNA-damage and preventing cancerous cell growth $[5,6]$. In spite of curcumin is a natural antioxidant known to possess therapeutic properties and has been reported to scavenge free radicals and to inhibit clastogenesis in mammalian cells [7]. Curcumin has been reported to induce a significant increase in the frequency of chromosomal aberrations in Chinese hamster ovary ( $\mathrm{CHO})$ cells [8]. So it was necessary to evaluate the genotoxic effects and histochemical changes induced in male rat cells as a result to oral administration of different doses of curcumin for four weeks.

\section{Materials and methods}

An experiment was carried out on male Wistar rats (Rattus norvegicus) weighing 150-200gm, receiving standard food and water ad libitum. Each experimental group consisted of 10 animals. The first group (negative control) received distilled water orally by gastric intubation. The second group (positive control) injected IP with single dose of $25 \mathrm{mg} / \mathrm{kg}$ cyclophosphamide. Other five groups received curcumin spice $(0.5,5,10,25$ and $50 \mathrm{mg} / \mathrm{kg}$ body weight). Curcumin was dissolved in distilled water and $1 \mathrm{ml} /$ animal of suspension given orally to male rat daily for four weeks. The dose 0.5 is the curcumin acceptance daily intake (ADI) and the other doses were chosen according to [9]. Twenty-four hours after the last administration, Animals were injected IP with colchicine solution Two hours later animals were killed by cervical dislocation. The femur bones were quickly separated one femur bone was used for preparation of micronucleus polychromatic erythrocytes according to method of [10]. While the other one was used for chromosomal preparation according to [11]. For histopathological and histochemical studies, paraffin sections of liver and kidneys were stained with $\mathrm{Hx}$ and E, Feulgen stain for DNA and periodic acid Schiff technique for mucopolysaccharide. DNA and PAS were evaluated as optical density values of their specific color using computer- assisted image analyzer. The analysis of variance test was used for the chromosomal aberrations data analysis. While the $t$ - test was used to analyse the data of MNPCEs and histochemical studies. 
Table 1: The frequencies of MNPCEs in male albino rate bone marrow cells of all experimental groups.

\begin{tabular}{|c|c|c|c|c|}
\hline & Total Counted & \multicolumn{2}{|c|}{ MNPCES } & \multirow[t]{2}{*}{ Mean \pm SD } \\
\hline & & No. & $\%$ & \\
\hline Negative control & 2000 & 94 & 1.57 & $5.67 \pm 2.16$ \\
\hline Positive control & 2000 & 604 & 10.07 & $\begin{array}{c}100.67 \pm 6.77 \\
* *\end{array}$ \\
\hline $0.5 \mathrm{mg} / \mathrm{kg}$ bw curcumin & 2000 & 91 & 1.52 & $\begin{array}{l}\mathrm{NS} \\
5.17 \pm 1.47 \\
\end{array}$ \\
\hline $5 \mathrm{mg} / \mathrm{kg}$ bw curcumin & 2000 & 142 & 2.37 & $\begin{array}{c}* * \\
23.67 \pm 4.59 \\
\end{array}$ \\
\hline $10 \mathrm{mg} / \mathrm{kg}$ bw curcumin & 2000 & 222 & 3.70 & $\begin{array}{c}* * \\
37.00 \pm 4.52 \\
*\end{array}$ \\
\hline $25 \mathrm{mg} / \mathrm{kg}$ bw curcumin & 2000 & 381 & 6.35 & $\begin{array}{c}* * \\
63.50 \pm 6.83 \\
\end{array}$ \\
\hline $50 \mathrm{mg} / \mathrm{kg}$ bw curcumin & 2000 & 587 & 9.78 & \begin{tabular}{|c|}
$* *$ \\
$97.83 \pm 3.31$ \\
$\mathrm{NS}$ \\
\end{tabular} \\
\hline
\end{tabular}

*significant comparison to $-\mathrm{ve}$ control at $(\mathrm{p}<0.05) * *$ significant compared to $-\mathrm{ve}$ control at $(0.01)$

- significant comparison to +ve control at $(\mathrm{p}<0.05)$ significant compared to +ve control at $(0.01)$

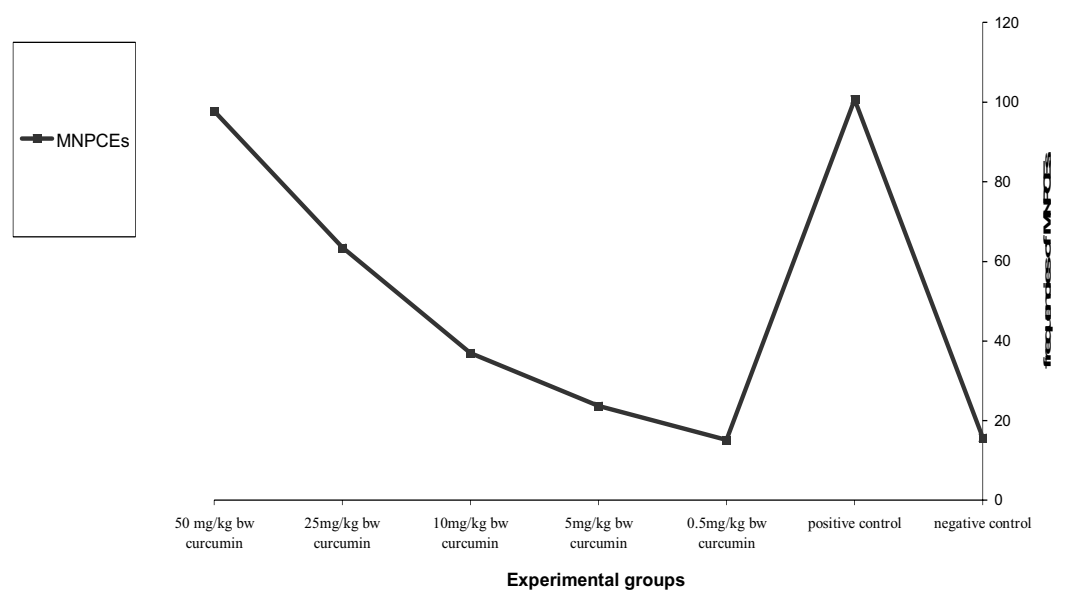

Figure 1: Frequencies of MNPCUs in male albino rat bone marrow cells of all experimental groups. 


\section{Results}

\subsection{Cytogenetical results}

Results of micronucleus test in bone marrow cells of male rats of all experimental groups are summarized in table 1 and presented in figure 1. Data indicated that curcumin exhibited a dose dependent increase in the frequency of MNPCEs when compared with negative control. Since the dose of $5 \mathrm{mg} / \mathrm{kg}$ bw induced significant increase at $(\mathrm{p}<0.05)$, whereas, the 10,25 and $50 \mathrm{mg} / \mathrm{kg}$ bw doses of curcumin induced significantly increase in the frequencies of MNPCEs at $(p<0.01)$ than control. At the comparison to positive control, results showed that there were statistically significant differences between the frequencies of MNPCEs of curcumin treated animals with doses $(0.5,5$ and $25 \mathrm{mg} / \mathrm{kg} \mathrm{bw})$ and positive control. In contrast, no statistically significant difference between the dose of $50 \mathrm{mg} / \mathrm{kg}$ bw and the positive control was observed.

Table 2: Frequency of different chromosomal aberration male rat bone marrow cells of different experimental groups.

\begin{tabular}{|c|c|c|c|c|c|c|c|}
\hline & \multicolumn{7}{|c|}{ Experimental groups } \\
\hline & 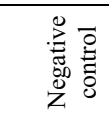 & 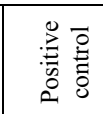 & 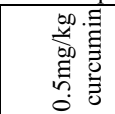 & 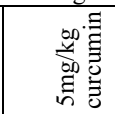 & 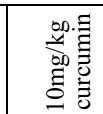 & 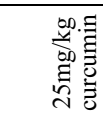 & 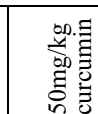 \\
\hline Hypo-ploidy & $\begin{array}{c}0.17 \mathrm{c} \\
\pm \\
0.41\end{array}$ & $\begin{array}{c}1.50 \mathrm{~b} \\
\pm \\
1.05\end{array}$ & $\begin{array}{c}0.50 \mathrm{c} \\
\pm \\
0.55\end{array}$ & $\begin{array}{c}0.83 \mathrm{c} \\
\pm \\
0.75\end{array}$ & $\begin{array}{c}1.50 \mathrm{~b} \\
\pm \\
0.55\end{array}$ & $\begin{array}{c}2.50 \mathrm{a} \\
\pm \\
0.55\end{array}$ & $\begin{array}{c}3.00 \mathrm{a} \\
\pm \\
0.00\end{array}$ \\
\hline Hyper-ploidy & $\begin{array}{c}0.00 \mathrm{~d} \\
\pm \\
0.00\end{array}$ & $\begin{array}{c}0.67 \mathrm{bc} \\
\pm \\
0.88\end{array}$ & $\begin{array}{c}0.00 \mathrm{~d} \\
\pm \\
0.00\end{array}$ & $\begin{array}{c}0.00 \mathrm{~d} \\
\pm \\
0,00\end{array}$ & $\begin{array}{c}0.50 \mathrm{~cd} \\
\pm \\
0.55\end{array}$ & $\begin{array}{c}1.17 \mathrm{ab} \\
\pm \\
0.41\end{array}$ & $\begin{array}{c}1.33 \mathrm{a} \\
\pm \\
0.52\end{array}$ \\
\hline Polyploidy & $\begin{array}{c}0.00 \mathrm{~b} \\
\pm \\
0.00\end{array}$ & $\begin{array}{c}1.83 \mathrm{a} \\
\pm \\
0.75\end{array}$ & $\begin{array}{c}0.00 \mathrm{~b} \\
\pm \\
0.00\end{array}$ & $\begin{array}{c}0.00 \mathrm{~b} \\
\pm \\
0.00\end{array}$ & $\begin{array}{c}0.00 \mathrm{~b} \\
\pm \\
0.00\end{array}$ & $\begin{array}{c}0.17 \mathrm{~b} \\
\pm \\
0.41\end{array}$ & $\begin{array}{c}1.67 \mathrm{a} \\
\pm \\
0.75\end{array}$ \\
\hline $\begin{array}{l}\text { Chromatid } \\
\text { gap }\end{array}$ & $\begin{array}{c}0.67 \mathrm{~d} \\
\pm \\
0.82\end{array}$ & $\begin{array}{c}4.83 \mathrm{a} \\
\pm \\
1.47\end{array}$ & $\begin{array}{c}1.00 \mathrm{~d} \\
\pm \\
0.63\end{array}$ & $\begin{array}{c}2.17 \mathrm{c} \\
\pm \\
0.41\end{array}$ & \begin{tabular}{|c|}
$2.67 \mathrm{bc}$ \\
\pm \\
0.52
\end{tabular} & $\begin{array}{c}3.33 \mathrm{~b} \\
\pm \\
0.82\end{array}$ & \begin{tabular}{|c}
$5.17 \mathrm{a}$ \\
\pm \\
0.52
\end{tabular} \\
\hline $\begin{array}{l}\text { Chromatid } \\
\text { break }\end{array}$ & $\begin{array}{c}0.33 \mathrm{~b} \\
\pm \\
0.52\end{array}$ & $\begin{array}{c}4.83 \mathrm{a} \\
\pm \\
1.03\end{array}$ & $\begin{array}{c}0.17 \mathrm{~b} \\
\pm \\
0.41\end{array}$ & $\begin{array}{c}0.83 \mathrm{~b} \\
\pm \\
0.41\end{array}$ & $\begin{array}{c}1.50 \mathrm{~b} \\
\pm \\
0.55\end{array}$ & $\begin{array}{c}2.00 \mathrm{a} \\
\pm \\
0.89\end{array}$ & $\begin{array}{c}2.67 \mathrm{a} \\
\pm \\
0.52\end{array}$ \\
\hline $\begin{array}{l}\text { Chromosome } \\
\text { break }\end{array}$ & $\begin{array}{c}0.00 \mathrm{c} \\
\pm \\
0.00\end{array}$ & $\begin{array}{c}1.00 \mathrm{a} \\
\pm \\
0.89\end{array}$ & $\begin{array}{c}0.00 \mathrm{e} \\
\pm \\
0.00\end{array}$ & $\begin{array}{c}0.0 \mathrm{de} \\
\pm \\
0.00\end{array}$ & $\begin{array}{c}0.17 \mathrm{~d} \\
\pm \\
0.41\end{array}$ & $\begin{array}{c}0.83 \mathrm{bc} \\
\pm \\
0.41\end{array}$ & $\begin{array}{c}1.33 \mathrm{~b} \\
\pm \\
0.75\end{array}$ \\
\hline Fragment & $\begin{array}{c}0.00 \mathrm{~d} \\
\pm \\
0.00\end{array}$ & $\begin{array}{c}3.00 \mathrm{a} \\
\pm \\
1.16\end{array}$ & $\begin{array}{c}0.33 \mathrm{~cd} \\
\pm \\
0.52\end{array}$ & $\begin{array}{c}0.83 \mathrm{bcd} \\
\pm \\
0.75\end{array}$ & $\begin{array}{c}1.17 \mathrm{~cd} \\
\pm \\
0.41\end{array}$ & $\begin{array}{c}1.67 \mathrm{~b} \\
\pm \\
1.05\end{array}$ & $\begin{array}{c}2.83 \mathrm{a} \\
\pm \\
0.75\end{array}$ \\
\hline Deletions & $\begin{array}{c}0.00 \mathrm{~b} \\
\pm \\
0.00\end{array}$ & $\begin{array}{c}0.50 \mathrm{a} \\
\pm \\
0.55\end{array}$ & $\begin{array}{c}0.00 \mathrm{~b} \\
\pm \\
0.00\end{array}$ & $\begin{array}{c}0.00 \mathrm{~b} \\
\pm \\
0.00\end{array}$ & $\begin{array}{c}0.00 \mathrm{~b} \\
\pm \\
0.00\end{array}$ & $\begin{array}{c}0.33 \mathrm{ab} \\
\pm \\
0.52\end{array}$ & $\begin{array}{c}0.67 \mathrm{a} \\
\pm \\
0.52\end{array}$ \\
\hline $\begin{array}{l}\text { Centromeric } \\
\text { attenuation }\end{array}$ & $\begin{array}{c}3.33 \mathrm{bc} \\
\pm \\
1.03\end{array}$ & $\begin{array}{c}5.17 \mathrm{a} \\
\pm \\
1.47\end{array}$ & $\begin{array}{c}2.33 \mathrm{c} \\
\pm \\
0.82\end{array}$ & $\begin{array}{c}4.67 \mathrm{ab} \\
\pm \\
1.37\end{array}$ & $\begin{array}{c}5.83 \mathrm{a} \\
\pm \\
1.49\end{array}$ & $\begin{array}{c}5.17 \mathrm{a} \\
\pm \\
1.17\end{array}$ & $\begin{array}{c}5.17 \mathrm{a} \\
\pm \\
1.17\end{array}$ \\
\hline $\begin{array}{l}\text { Total } \\
\text { chromosomal } \\
\text { aberrations }\end{array}$ & $\begin{array}{c}4.50 \mathrm{e} \\
\pm \\
1.38\end{array}$ & $\begin{array}{l}22.83 \mathrm{a} \\
\pm \\
2.71\end{array}$ & $\begin{array}{c}4.33 \mathrm{e} \\
\pm \\
0.82\end{array}$ & $\begin{array}{c}9.17 \mathrm{~d} \\
\pm \\
0.75\end{array}$ & $\begin{array}{c}13.33 \mathrm{c} \\
\pm \\
1.03\end{array}$ & $\begin{array}{c}17.17 \mathrm{~b} \\
\pm \\
0.75\end{array}$ & $\begin{array}{c}23.83 \mathrm{a} \\
\pm \\
1.60\end{array}$ \\
\hline
\end{tabular}

(Means with different letters within each column are significant at 5\% level.) 
Table 2 and figure 2 illustrate the mean values of structural and numerical chromosomal aberrations in bone marrow cells of all experimental groups. Results showed that curcumin accepted daily intake (ADI) dose not induced significant difference as compared to negative control. In bone marrow cells of animals administered with the other four doses, a dose dependant increase in the frequencies of all individuals and total chromosomal aberrations were observed. At the comparison between the frequencies of all individuals and total chromosomal aberrations induced in positive control and those of different curcumin doses treated animals, results showed that there were significant differences $(p<0.01)$ between positive control and groups of $0.5,5,10$, and $25 \mathrm{mg} / \mathrm{kg}$ curcumin. Whereas, there was no significant difference between positive control and the group of $50 \mathrm{mg} / \mathrm{kg}$ curcumin treated animals. These results indicated that the high dose of curcumin $(50 \mathrm{mg} / \mathrm{kg})$ is the more effective to induce significant increase in the frequencies of MNPCEs and chromosomal aberrations in rat bone marrow cells.
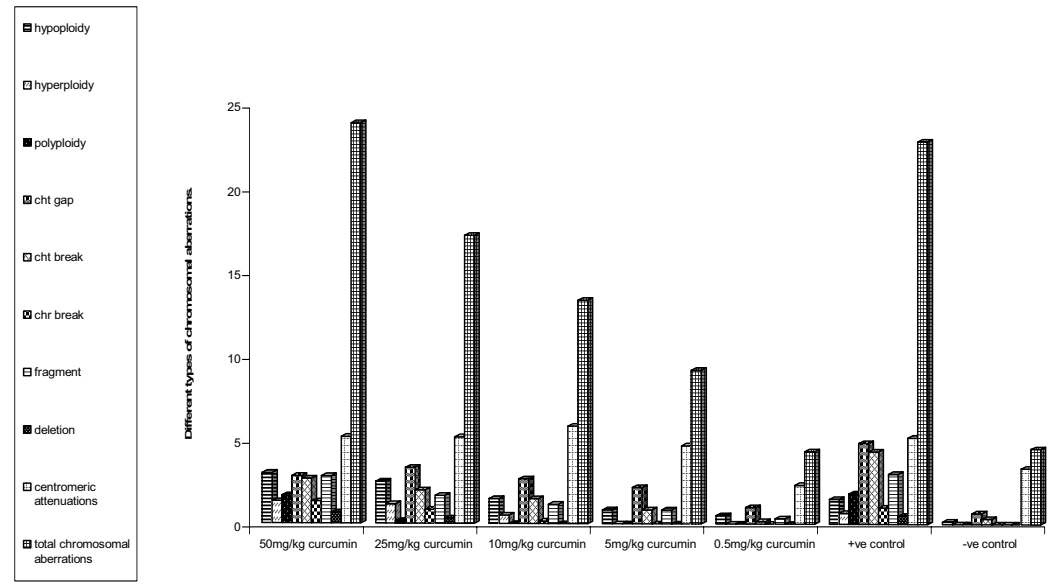

Figure 2: Frequencies of different chromosomal aberrations induced in all experimental groups.

\subsection{Histological and histochemical results}

The microscopic observation in control and $0.5 \mathrm{mg} / \mathrm{kg}$ curcumin treated rats showed normal structure of hepatic lobules in which the hepatocytes arranged in cords radiating from the central vein. Liver sections of curcumin treated rats revealed cytoplasmic degeneration, necrosis, cytoplasmic vacuolar damage and dilated and congested with few inflammatory cells in the portal tract. These observations were highly pronounced in rats treated with 5,10 and $25 \mathrm{mg} / \mathrm{kg}$ curcumin and were prominent in rat treated with $50 \mathrm{mg} / \mathrm{kg}$ curcumin (fig 3). As regard to kidney tissues, histological observation of sections of animals receiving $0.5,5$, and $10 \mathrm{mg} / \mathrm{kg}$ of curcumin showed that almost all the renal tubules were normal without histopathological changes. While, the kidney tissues of animals 
received the dose of $25 \mathrm{mg} / \mathrm{kg}$ of curcumin showed some picture of damage in tubular epithelial cells, thickening in blood vessels, mild cellular infiltration and interstitial hemorrhage. While, the renal tubules of animals received the dose of $50 \mathrm{mg} / \mathrm{kg}$ of curcumin revealed advanced tubular degeneration, increased in cellular infiltration, interstitial hemorrhage and some glomeruli were damage (fig 4). Histochemical evaluation to DNA and PAS were measured as mean value per nucleus by image analyzer. DNA was demonstrated by using Feulgen reaction technique. The Results showed that curcumin different doses induced significant decrease $(p<0.01)$ in the mean value of DNA content of liver tissues when compared with control (table 3 and fig 5). In kidney cells, also results showed that the curcumin induced significant decrease $(\mathrm{p}<0.01)$ in the mean value of DNA content than in control (table 4 and fig 6). As regard to PAS + ve material, curcumin caused significant decrease $(p<0.01)$ in the level of PAS in both liver and kidney tissues of all groups as compared to control as shown in (tables 5, 6 and fig 7,8). while in renal tubule, all treated groups revealed moderate reaction in the basement membrane and brush border.

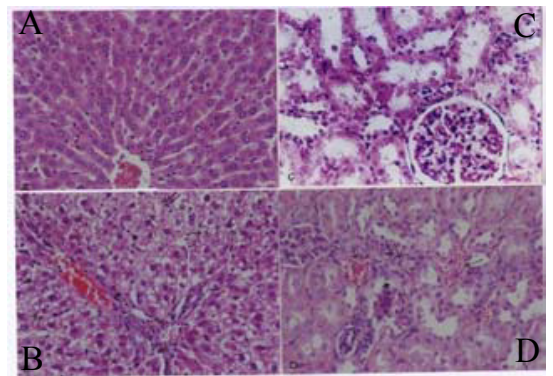

Figure 3: $\quad$ Section of control and Figure 4: treated liver (A and B) and kidneys ( $\mathrm{C}$ and $\mathrm{D})$ $\mathrm{H}$ and $\mathrm{E} \mathrm{X} 300$.

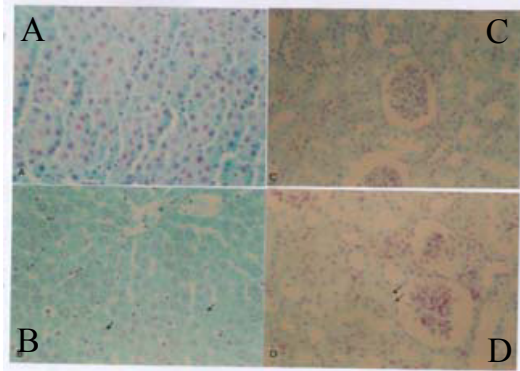

Section of control and treated liver (A and $\mathrm{B})$ and kidneys (C and $\mathrm{D})$ Feulgen reaction $\mathrm{X} 300$.

Table 3: Mean values of DNA content in liver tissues of all treated groups.

\begin{tabular}{|l|c|c|c|c|c|c|}
\hline Groups & Control & $0.5 \mathrm{mg} / \mathrm{kg}$ & $5 \mathrm{mg} / \mathrm{kg}$ & $10 \mathrm{mg} / \mathrm{kg}$ & $25 \mathrm{mg} / \mathrm{kg}$ & $50 \mathrm{mg} / \mathrm{kg}$ \\
\hline \multirow{2}{*}{ DNA } & 0.35 & 0.25 & 0.22 & 0.20 & 0.18 & 0.18 \\
Content & \pm & \pm & \pm & \pm & \pm & \pm \\
& $2.31 \mathrm{E} 02$ & $\mathbf{3 . 0 1 E - 0 2}$ & $2.20 \mathrm{E}-02$ & $2.58 \mathrm{E}-02$ & $\mathbf{0 . 1 9 E}-\mathbf{0 2}$ & $1.49 \mathrm{E}-02$ \\
\hline
\end{tabular}




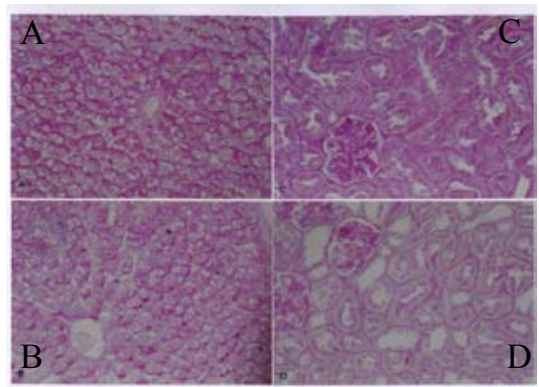

Figure 5: $\quad$ Section of control and treated liver (A and B) and kidneys (C and D) PAS X300.

Table 4: Mean values of DNA content in kidney tissues of all treated groups.

\begin{tabular}{|l|c|c|c|c|c|c|}
\hline Groups & Control & $0.5 \mathrm{mg} / \mathrm{kg}$ & $5 \mathrm{mg} / \mathrm{kg}$ & $10 \mathrm{mg} / \mathrm{kg}$ & $25 \mathrm{mg} / \mathrm{kg}$ & $50 \mathrm{mg} / \mathrm{kg}$ \\
\hline DNA & 0.30 & 0.25 & 0.25 & 0.24 & 0.22 & 0.22 \\
Content & \pm & \pm & \pm & \pm & \pm & \pm \\
& $2.87 \mathrm{E}-02$ & $3.71 \mathrm{E}-02$ & $3.25 \mathrm{E}-02$ & $2.75 \mathrm{E}-02$ & $1.87 \mathrm{E}-02$ & $2.46 \mathrm{E}-02$ \\
\hline
\end{tabular}

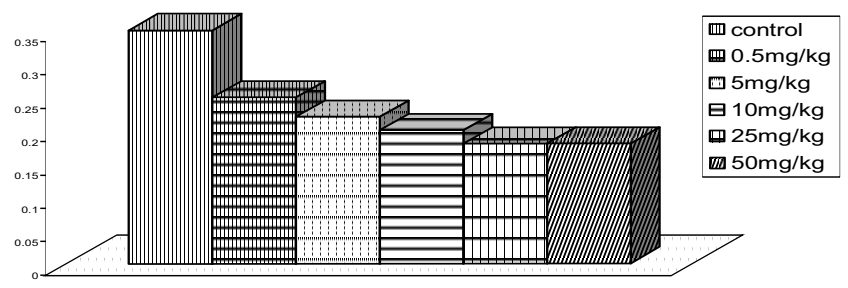

Figure 6: Mean values of DNA content in hepotocytes of all treated groups.

Table 5: Mean values of PAS content in hepatic cells of all treated groups.

\begin{tabular}{|l|c|c|c|c|c|c|}
\hline Groups & Control & $0.5 \mathrm{mg} / \mathrm{kg}$ & $5 \mathrm{mg} / \mathrm{kg}$ & $10 \mathrm{mg} / \mathrm{kg}$ & $25 \mathrm{mg} / \mathrm{kg}$ & $50 \mathrm{mg} / \mathrm{kg}$ \\
\hline $\begin{array}{l}\text { DNA } \\
\text { Content }\end{array}$ & $\begin{array}{c} \pm .42 \\
\pm\end{array}$ & $\begin{array}{c} \pm .18 \\
\pm\end{array}$ & $\begin{array}{c}0.13 \\
\pm\end{array}$ & $\begin{array}{c}0.27 \\
\pm\end{array}$ & $\begin{array}{c}0.13 \\
\pm\end{array}$ & $\begin{array}{c} \pm .28 \\
\pm \\
\end{array}$ \\
\hline
\end{tabular}

Table 6: Mean values of PAS content in renal cells of all treated groups.

\begin{tabular}{|l|r|r|r|c|c|c|}
\hline Groups & Control & $0.5 \mathrm{mg} / \mathrm{kg}$ & $5 \mathrm{mg} / \mathrm{kg}$ & $10 \mathrm{mg} / \mathrm{kg}$ & $25 \mathrm{mg} / \mathrm{kg}$ & $50 \mathrm{mg} / \mathrm{kg}$ \\
\hline $\begin{array}{c}\text { DNA } \\
\text { Content }\end{array}$ & $\begin{array}{c}0.37 \\
\pm\end{array}$ & $\begin{array}{c}0.31 \\
\pm\end{array}$ & $\begin{array}{c}0.25 \\
\pm\end{array}$ & $\begin{array}{c}0.28 \\
\pm\end{array}$ & $\begin{array}{c}0.28 \\
\pm\end{array}$ & $\begin{array}{c} \pm .28 \\
\pm \\
1.20 \mathrm{E}-02\end{array}$ \\
\hline
\end{tabular}




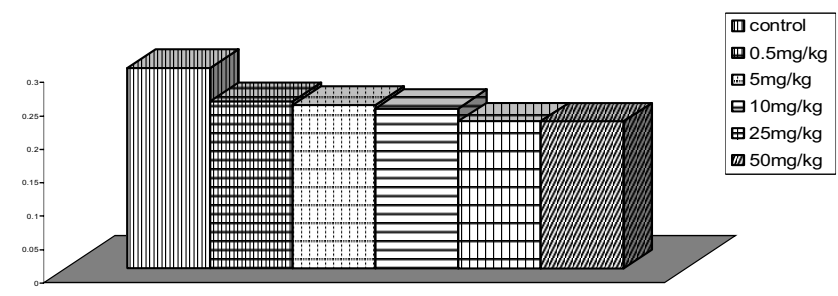

Figure 7: Mean values of DNA content in kidney cells of all treated groups.

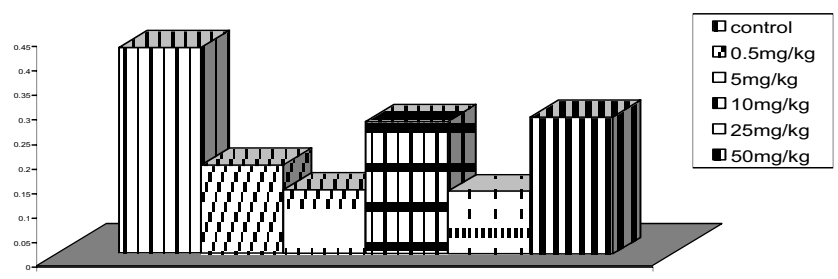

Figure 8: $\quad$ Mean values of PAS content in hepatic cells of all groups.

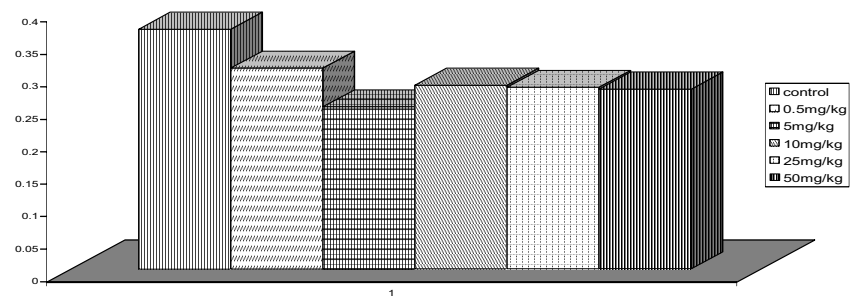

Figure 9: Mean values of DNA control in hepotocytes of all treated groups.

\section{Discussion}

Curcumin has been used as a herbal medicine. Curcumin shows a variety of physiological and pharmacological effects. Several studies indicate curcumin to be anticarcinogenic [12] and anti-inflammatory [13] Curcumin further shows antioxidant properties, it acts as a superoxide radical scavenger [7, 14] and as a singlet oxygen guencher [15]. Contrary to the antioxidant nature of curcuminoids, much evidence for cytotoxic properties of curcumin was reported, and its cytotoxicity is suggested to be due to production of reactive oxygen species and causes oxidative DNA damage [16]. The cytogenetic results of the present study demonstrate that the curcumin administration induced a dose dependent significant increase in the frequencies of MNPCEs and total chromosomal aberrations in bone marrow cells of male rats. Histochemical studies confirmed these results. Since, the histochemical investigation of the present study showed that curcumin caused significant decrease in DNA content 
in both liver and kidney tissues of treated animals. Many studies have found that the antitumor- promoting effects of curcumin, could be contributed to its apoptosis-inducing activity. Since, curcumin induces a growth arrest in the G2/M-phase of the cell cycle, it exerts profound effects on mitotic spindle organization and leads to formation of monopolar spindles that are unable to segregate chromosomes normally. Cells with monopolar spindles arrest in $\mathrm{M}$ phase for extended periods, and eventually leave mitosis and enter interphase with grossly aberrant nuclei consisting of numerous large micronuclei.

The production of cells with extensive micronucleation are due to its ability to disrupt normal mitosis, and raises the possibility that curcumin may promote genetic instability under some circumstances [17]. Histochemical examination of PAS + ve material indicated that curcumin caused significant decrease of PAS content in both liver and kidney tissues of all groups. The decrease in PAS +ve material observed in this study was interpreted due to the most probably consequent to the degenerative changes [18]. Previous literatures have demonstrated that antioxidants can act as prooxidants under some circumstances [19]. It is found that b-carotene [20], vitamin $\mathrm{E}$ [21], quercetin [22], $\mathrm{N}$-acetylcysteine [23], and caffeic acid [24] can act as potent DNA damaging agents. Also, a potential clastogenic effect of known antioxidant compounds has been reported by others. S-vanillin were enhanced the chromosome aberrations induced by alkylating agents in cultured Chinese hamster cells [25]. Bcarotene and ascorbic acid were enhanced the clastogenicity induced by BLM in CHO cells [26and27].Curcumin, like ascorbic acid, can become a pro-oxidant agent depending on the redox state of the biological environment [28]. Therefore, the mutagenic effects of curcumin found in the present work could be explained by the fact that curcumin would act as a pro-oxidant agent at the highest concentrations tested under the conditions of the present study. Clastogenic effects of curcumin were also observed by others. Curcumin showed a slight increase in the number of chromosomal aberrations in treated mice [29]. Curcumin acute and chronically treated induced a significant increase in SCE and a weak increase in the frequency of chromosomal aberrations in mice and rats [30]. The histological examination of the present study also showed that curcumin induced hepatotoxicity. Liver tissues of curcumin treated animals revealed highly pronounced cytoplasmic degeneration, necrosis and cytoplasmic vacuolar damage. In addition, the portal tract was dilated and congested with few inflammatory cells were present in animals treated with curcumin high dose. Other studies confirmed this result. It was reported that the administration of high curcumin dose for longer duration showed hepatotoxicity represented in focal necrosis or focal necrosis with regeneration both in mice and rats $[31,32]$. Thus putative chemo-preventive antioxidants may have carcinogenic effect. Therefore, much consideration to safety should be required when curcumin is used for nutrition supplement. 


\section{References}

[1] Chainani-Wu N. (2003): Safety and anti-inflammatory activity of curcumin: a component of tumeric (Curcuma longa). J Altern Complement Med., 9(1):161-8. 2-

[2] Lin J.K. \& Shiau S.Y. (2001): Mechanism of cancer chemoprevention by curcumin. Proc. Natl. Sci. Counc.25 (2): 59-66.

[3] Blasiak J., Trzeciak A. \& Kowalik J. (1999a): Curcumin damages DNA in human gastric mucosa cells and lymphocytes. J Environ Pathol Toxicol Oncol. 18(4):271-6.

[4] Deeb D., Xu Y.X. Jiang H., Gao X,. Janakiraman N., Chapman R.A. \& Gautam S.C. (2003): Curcumin (diferuloyl-methane) enhances tumor necrosis factor-related apoptosis-inducing ligand-induced apoptosis in LNCaP prostate cancer cells. Mol Cancer Ther. 2 (1):95-103.

[5] Chen, H. W. \& Huang, H. C.(1998): Effect of curcumin on cell cycle progression and apoptosis in vascular smooth cells. Br. J. Pharmacol., 124, 1029-1040.

[6] Martin-Cordero C., Lopez-Lazaro M., Galvez M. \& Ayuso M. J.(2003): Curcumin as a DNA topoisomerase II poison. J. Enzyme Inhib. Med.Chem.18:505-509.

[7] Ruby, A.J., Kuttan, G., Babu, K.D., Rajasekharan, K.N. and Kuttsn, R.(1995): Antitumor and antioxidant activity of natural curcuminoids. Cancer Lett. 94: 79-83.

[8] Araujo MC, Antunes L.M., Takahashi CS. (2001): Protective effect of thiourea, a hydroxyl-radical scavenger, on curcumin-induced chromosomal aberrations in an in vitro mammalian cell system. Teratog Carcinog Mutagen. 21(2):175-80.

[9] Choudhary D, Chandra D, Kale RK. (1999): Modulation of radioresponse of glyoxalase system by curcumin. J Ethnopharmacol. 64(1): 1-7.

[10] Salamone M.F., Heddle J.A. and Katz M. (1980) : The mutagenic activity of 41 compounds on the in vivo micronucleus assay, In : J Ashby and Fde Serres (F. DS.), proceedings of International program for THE Evaluation of Short- TerM Tests for Carcinogenicity. Elsever. Amsterdam.

[11] Yosida, T.H. and Amano K. (1965): Autosomal polymorphic in laboratory bred and Wild Norway rats -Rattus norvegicus, found in Misima.Chromosoma, 16:658-66.

[12] Conney, A.H., Lysz, T., Ferraro, T., Abidi, T.F., Manchand, P.S., Laskin, J.D. and Huang, M.T. (1991): Inhibitory effect of curcumin and some related dietary compounds on tumor promotion and arachidonic acid metabolism in mouse skin. Adv. Enzyme Regul.31 385-396.

[13] Huang M.T., Lysz, T., Ferraro, T., Abidi, T.F., Laskin, J.D. and Conney, A.H (1991): Inhibitory effects of curcumin on in vitro lipoxygenase and cytooxygenase activities in mouse epidermis. Cancer Res. 51: 813-819

[14] Reddy, A.C. and Lokesh, B.R. (1994): Studies on the inhibitory effects of curcumin and gingerol on the formation of reactive oxygen species and oxidation of ferrous iron. Moll. Cell. Biochem. 137: 1-8 
[15] Das, K.C. and Das, C.K.(2002) : Curcumin (diferuloylmethane), a singlet oxygen (o2) quencher. Biochem. Biophys. Res. Commun. 295:62-66.

[16] Sakano K. and Kawanishi S. (2002): Metal- mediated DNA damage induced by curcumin in the presence of human cytochrome P450 isozymes. Arch. Biochem. Biophys. 405(2) :223-230.

[17] Holy, J.M. (2002): Curcumin disrupts mitotic spindle structure and induces micronucleation in MCF-7 breast cancer cells., Mut. Res. 518(1): 71-84.

[18] Khadiga I.M.M.\& Shadia, M. M. (1995) : Structural changes in rat induced by dietary addition of monosodium glutamate. Egypt. J. Histol.(2): 423-430.

[19] Yoshino, M., Haneda, M., Naruse, M., Htay, H.H., Tsubouchi, R., Qiao, S.L., Li, W.H., Murakami, K. and Yokochi, T. (2004): Prooxidant activity of curcumin: copper-dependent formation of 8-hydroxy-2deoxyguanosine in DNA and induction of apoptotic cell death. Toxicology in vitro,18(6): 783-789.

[20] Murata M. and Kawanishi S. (2000): oxidative DNA damage by vitamin A and Its Derivative via Superoxide Generation. J Biol Chem,. 275(3,): 2003-2008

[21] Yamashita N, Murata M, Inoue S, Burkitt MJ, Milne L, Kawanishi S.(1998): Alpha-tocopherol induces oxidative damage to DNA in the presence of copper(II) ions. Chem Res Toxicol. 11(8):855-62.

[22] Yamashita N. and Kawanishi S.(2000) : Distinct mechanisms of DNA damage in apoptosis induced by quercetin and luteolin. Free Radic Res. 33(5):623-33.

[23] Oikawa S., Yamada K., Yamashita N., Tada-Oikawa S. and Kawanishi S. (1999): $N$-acetylcysteine, a cancer chemopreventive agent, causes oxidative damage to cellular and isolated DNA Carcinogenesis, 20(8): 1485-1490.

[24] Inoue S., Ito K, Yamamoto K. and Kawanishi S. (1992): Caffeic acid causes metal-dependent damage to cellular and isolated DNA through H2O2 formation Carcinogenesis, (13): 1497-1502.

[25] Matsumura, H., Watanabe, K. and Ohta, T. (1993). s-Vanillin enhances chromosome aberrations induced by alkylating agents in cultured Chinese hamster cells. Mutat. Res. 298: 163-168.

[26] Salvadori, D.M.F., Ribeiro, L.R. and Natarajan, A.T. (1994). Effect of bcarotene on clastogenic effects of mitomycin $\mathrm{C}$, methyl methanesulphonate and bleomycin in Chinese hamster ovary cells. Mutagenesis 9: 53-57.

[27] Cozzi, R., Ricordy, R., Agliti, T., Gatta, V., Perticone, P. and De Salvia, R. (1997). Ascorbic acid and b-carotene as modulators of oxidative damage. Carcinogenesis 18: 223-228.

[28] Sahu, S.C. and Washington, M.C. (1992). Effect of ascorbic acid and curcumin on quercetin-induced nuclear DNA damage, lipid peroxidation and protein degradation. Cancer Lett. 63: 237-241. 
[29] Mukhopadhyay, M.J., Saha, A. and Mukherjee, A. (1998): Studies on the anticlastogenic effect of turmeric and curcumin on cyclophosphamide and mitomycin $\mathrm{C}$ in vivo. Food Chem. Toxicol. 36: 73-76.

[30] Giri, A.K., Das, S.K., Talukder, G. and Sharma, A. (1990). Sisterchromatid exchange and chromosome aberrations induced by curcumin and tartrazine on mammalian cells in vivo. Cytobios 62: 111-118.

[31] Deshpandea, S.S., Lalithab, V.S., Inglec, A.D, Rasted, A.S., Gadred, S.G. and Marua G.B. (1998): Subchronic oral toxicity of tumeric and ethanolic tumeric extract in female mice and rats. Toxicol. Lett. 95(3): 183-193.

[32] Kandarkar S.V., Sawant S.S., Ingle A.D., Deshpande S.S. and Maru G.B. (1998): Subchronic oral hepatotoxicity of tumeric in mice histopathological and ultrastructural studies. Indian J Exp. Biol. 36(7): 675-679. 